\title{
CRITICAL ACCOMMODATION INFORMATION FOR TRAVEL
} OPINION LEADER

\author{
Chien $\mathrm{Mu}$ Yeh \\ Tamkang University, Taiwan \\ E-mail: chienmu.yeh@gmail.com
}

Submission: 3/18/2019

Revision: 5/2/2019

Accept: 5/17/2019

\begin{abstract}
Potential tourists search for accommodation information once they decide to travel. Travel opinion leaders are critical accommodation information providers for potential tourists. However, we know little about travel opinion leaders' perceived importance of accommodation information. The current study examined the relationship between travel opinion leadership and perceived importance of accommodation information. Results showed that there were significant differences in the perception of important accommodation information between the high and low travel opinion leadership groups. These results make theoretical and practical implications for tourism research and accommodation managers.
\end{abstract}

Keywords: opinion leaders, accommodation information, information search behavior 
ISSN: 2236-269X

DOI: 10.14807/ijmp.v11i1.1021

\section{INTRODUCTION}

Tourists search for information in the early stage of the decision-making process (COOK; YALE; MARQUA, 2018). Because core tourism products are experiences, information and advice are important for potential tourists (FODNESS; MURRAY, 1999; HYDE, 2008). Opinion leaders have been identified as important information sources for potential tourists (LEE; LAW; MURPHY, 2011). They play the role of the leader of information acceptance and product use (POLEGATO; WALL, 1980).

Opinion leaders use more information sources to enrich their knowledge in their field (FLYNN; GOLDSMITH; EASTMAN, 1996; ROGERS, 1996) and interpret the meaning of information content for other consumers who seek advice (PAN; LITVIN; O’DONNELL, 2007). Driven by altruism, opinion leaders generally engage in word-of-mouth communication and provide potential consumers with product information and buying advice (DAVIS; GUITINAN; JONES, 1979). Therefore, opinion leaders are able to influence other consumers' attitude and behavior (FLYNN et al., 1996).

Tourism firms exchange information with tourists through different channels to market products, enhance customer relationships and influence tourists' buying decision (GURSOY; MCCLEARY, 2004; KIM; LEHTO; MORRISON, 2007; PAN; FESENMAIER, 2006). Providing relevant and appropriate product information is the key to the success of tourism firms (KIM et al., 2007). For effective information communication, it is not enough to simply provide products information. Instead, given the important role of opinion leaders, tourism managers must understand whether product information in, for example, their website, brochure and guidebook, cater to the needs of opinion leaders. Without this understanding, it is difficult to make appropriate marketing communications with travel opinion leaders.

While the issue of an opinion leader is extensively discussed in the tourism literature, few studies empirically examine the behavior pattern of travel opinion leaders. Among them, information search behavior of opinion leaders is usually examined. They specifically focus on such issues as search patterns and usages of information sources (JAMROZY; BACKMAN; BCKMAN, 1996). However, little tourism research has attempted to investigate the perceived importance of information for travel opinion leaders. As a result, knowledge of what information tourism firms must communicate with opinion leaders is limited. Therefore, the main purpose of the current study is to fill the identified gap. 
DOI: 10.14807/ijmp.v11i1.1021

Like general tourists, travel opinion leaders face a great deal of information and search product information from different information sources (JAMROZY et al., 1996; PAN; FESENMAIER, 2006). It is reasonable to assume that travel opinion leaders can not conduct effective word-of-mouth marketing if they do not gain the needed product information from product providers. Therefore, with the growth of the tourism market, tourism managers should understand travel opinion leaders' perception of important information so as to make better information development decisions.

The current study focuses on accommodation information search behaviors of travel opinion leaders because potential tourists generally search for accommodation information once they make a decision on taking a trip (PAN; FESENMAIER, 2006). More specifically, the main purposes of the current research are to investigate the underlying dimensions of perceived importance of accommodation information and to analyze differences in the perceived importance of accommodation information in means of travel opinion leadership.

\section{LITERATURE REVIEW}

\subsection{Information Search}

Mountinho (1987) defines information search as a need to consult different information sources before making a purchasing decision. In the tourism sector, Fodenss and Murray (1997) argued that information search is a procedure in which tourists use a variety of information sources to plan their trip. In fact, potential tourists seek information for choosing a destination, attractions, travel patterns, onsite activities and lodging. They seek information to enhance the quality of their leisure trip by decreasing the associated risks and uncertainties (FODNESS; MURRAY, 1997; QUINTAL; LEE; SOUTAR, 2010).

It is widely acknowledged that tourism information search includes two major components: internal search and external search (COOK et al., 2018; HYDE, 2008; KERSTETTER; CHO, 2004; KIM et al., 2007). Tourists usually collect information from their long term memory or past experience first. If the internal search cannot provide appropriate or sufficient information for decision making, tourists search information from the external environment. External information search relies on marketing-dominated sources, such as advertising, magazines, newspapers, salespeople, product trial and brochure, and nonmarketing-dominated sources, such as family, friends, relatives and opinion leaders (COOK et al., 2018; FODNESS; MURRAY, 1998; KIM et al., 2007). 
INDEPENDENT JOURNAL OF MANAGEMENT \& PRODUCTION (IJM\&P)

http://www.ijmp.jor.br

v. 11, n. 1, January-February 2020

ISSN: $2236-269 X$

DOI: 10.14807/ijmp.v11i1.1021

Empirical tourism studies on information search have been investigated from different perspectives, such as the amount of search (QUINTAL et al., 2010), the search process (CHOI, et al., 2011; Ho, LIN; CHEN, 2012; PAN; FESENMAIER, 2006; PAN et al., 2007) and situational behavior (CARNEIRO; CROMPTON, 2010; RAMKISSOON; UYSAL, 2011). For example, Quintal et al. (2010) reported that the amount of information search was positively related to uncertainty avoidance and negatively related to risk avoidance. Choi et al. (2011) studied Chinese tourists to Macau and found that travel decision-making and information search involved a dynamic process. Travel decision-making and information search varied across travel stages.

Ho et al. (2012) identified a dynamic tourism information search process in both online and offline situations. Similarly, Pan and Fesenmaier (2006) studied online information search behaviors and found that tourist online information search behaviors followed a hierarchical procedure. Tourists searched for accommodation information once they decide the destination. In Pan et al.'s (2007) study, tourists mostly searched accommodation information together with other tourism information, such as attractions, destinations and transportation. Carneiro and Crompton (2010) examined the influence of involvement, familiarity and constraints on information search behavior. Their results showed that financial constraints, high involvement and less familiarity encouraged people to search more tourism information. Ramkissoon and Uysal (2011), in their study on culture tourism, found the influence of perceived authenticity, information search behavior, motivation and destination imagery on the cultural behavioral intentions.

\subsection{Opinion Leaders}

Opinion leaders have been recognized as a critical segment for marketers to target because of their influence on other consumers (COULTER; FEICK; PRICE, 2002; NAIR; MANCHANDA; BHATIA, 2010; YIYI et al., 2018). Through word-of-mouth communication, opinion leaders deliver product information, provide comments and give advice and direction to potential consumers about search, purchase and use of products (FLYNN; GOLDSMITH; EASTMAN, 1994; HOWELL; SHAW; ALVAREZ, 2015; LI; DU, 2011).

Word-of-mouth marketing is an informal way of delivering product information among potential customers (LI; DU, 2011; WESTBROOK, 1987). It is regarded to be more effective than traditional marketing (DONATON, 2003; TRUSOV; BUCKLIN; PAUWELS, 2009; 
DOI: 10.14807/ijmp.v11i1.1021

KIM; HOWARD; ADLER, 2015; WEIMANN, 1994). Therefore, researchers and practitioners have been interested in identifying opinion leaders' characteristics.

The concept of opinion leaders has also been studied from different perspectives, such as public issues (WEIMANN, 1991), health care (VALENTE; PUMPUANG, 2007), product diffusion (IYENGAR; VAN DEN BULTE; VALENTE, 2011), digital world (CHIREGI; NAVIMIPOUR, 2016; GOLDENBERG et al., 2009; LAYONS; HENDERSON, 2005; VAN ECK; JAGER; LEEFLANG, 2011; YIYI et al., 2018), physician prescription behavior (NAIR et al., 2010) and consumer products (COULTER et al., 2002; FLYNN, 1994; GOLDSMITH; HOFACKER, 1991; HOWELL et al., 2015).

The above studies have identified a number of characteristics of opinion leaders. Although the findings are different based on the type of product and domain, opinion leaders are generally found to be more active, innovative, self-confident and self monitoring. They occupy central positions in their social network and are willing to share information. Moreover, they get more involved in products, more actively search information, have more influential power, use more information sources and possess more knowledge in their field. Finally, they are better at product judgment and are better communicators than their peers.

In the tourism literature, there are limited empirical studies on opinion leaders. Among these few studies, Kim et al. (2015) found that service qualities positively influenced opinion leaders' intentions to conduct word-of-mouth marketing online. Smerecnik and Andersen (2011) identified that opinion leaders in the hotel and resort context were highly correlated with sustainability innovations and environmental communication. In addition, travel opinion leaders were recognized to be more sociable, read more travel magazines and take more and longer trips than non-opinion leaders $(\mathrm{OH}, 1997)$.

\subsection{Rationale for the Study}

Based on the above reviews, existing studies have enriched literature on tourism information search. While potential tourists search accommodation information once they decide to take a trip, none of the existing studies has examined what accommodation information is important. Moreover, existing studies have profiled the characteristics of opinion leaders from a variety of perspectives. No evidence was found in the existing literature on travel opinion leaders with respect to the perceived importance of accommodation information.

As such, studying this issue is significant and unique. Traveling products are usually intangible goods (COOK et al., 2018). Prospective tourists cannot evaluate these products 
DOI: 10.14807/ijmp.v11i1.1021

before the actual experience. They tend to rely on the opinions of others, thus emphasizing the importance of travel opinion leaders (LEWIS; CHAMBERS, 2000; MURPHY; MASCARDO; BENCKENDORFF, 2007).

Moreover, many tourism products are perishable and regarded as high-risk offerings. Opinion leaders' evaluation of the information is usually an important reference when prospective tourists make decisions (LEWIS; CHAMBERS, 1989). Tourism firms must provide necessary information in order for opinion leaders to evaluate products. Therefore, understanding what accommodation information is important for travel opinion leaders is critical for effective marketing communication.

\section{METHODOLOGY}

\subsection{Sampling}

A convenience sample of 171 senior students at the Lanyang Campus, Tamkang University, Taiwan was used to gather data. A self-reported questionnaire was delivered to respondents. A total of 148 (86.55\%) valid questionnaires were returned with anonymity. The current study used student samples to examine the travel information search behavior of opinion leaders because the student tourist market is a significant market in the tourism sector (REISINGER; MAVONDO, 2004; KIM; CHOI; KIM, 2013). Students relatively have more opportunities and time, such as semester breaks, to travel or stay in a destination than general tourists (THEUNS, 1992). As such, using student samples is appropriate.

\subsection{Instrument}

There are three sections in the survey instrument. In the first section, demographic data, such as age, and traveling behaviors, such as traveling frequency and information sources, were presented. Secondly, the level of opinion leadership was measured by a scale initially designed by Flynn et al., (1996). The scale was developed to measure opinion leadership in any specific area. Respondents of the current study were required to evaluate the degree to which they perceived themselves as travel opinion leaders by using a 5-point Likert scale (from 1= strongly disagree to $5=$ strongly agree).

In the third section, respondents were asked to measure the level of perceived importance of accommodation information. To develop the measurement, a focus group interview, including eight students, was conducted. Interviewees were asked to offer comments about perceived importance of accommodation information. 28 questions were generated in the focus group interview. A pilot test was then performed with ten students to seek changes 
DOI: 10.14807/ijmp.v11i1.1021

and clarity of wording and questions. As a result, no modification was needed since respondents did not have any comments. Respondents were asked to use a 5-point Likert scale (from 1= not important at all to $5=$ very important) to measure the perceived importance of accommodation information.

\subsection{Data analysis}

There were four steps of data analysis. First, a series of exploratory factor analyses were conducted to clarify the underlying factors of two scales, travel opinion leadership and perceived importance of accommodation information. Second, a series of confirmatory factor analyses were performed to ensure construct validity. Third, a regression analysis was used to examine whether travel opinion leadership influenced the perceived importance of accommodation information. Finally, the current study separated respondents into three groups based on the level of opinion leadership: less than 33.33th percentile (Low Travel Opinion Leadership group-LowTOL, $\mathrm{n}=58$ ), from 33.33th to 66.66th percentile (Middle Travel Opinion Leadership group-MidTOL, n=47) and more than 66.66th percentile (High Travel Opinion Leadership group-HighTOL, $n=43$ ). Then, to compare the differences in the perceived importance of accommodation, a chi-square test and one-way analysis of variance (ANOVA) test were performed.

\section{RESULTS}

An exploratory factor analysis with oblique rotation was employed to explore the underlying dimensions of the opinion leadership scale. The value of KMO (0.71) and the result of Bartlett's Test of Sphericity $(\mathrm{p}<.001)$ showed that it was appropriate to conduct a factor analysis. The analysis initially generated two factors with 6 items. After deleting one item which had a cross loading, two factors with 5 items explaining $78.76 \%$ of the total variance were produced to measure the level of a travel opinion leader. Eigenvalues of these two factors were greater than 1 and factor loading of all items were above 0.5 . They were named as Advice and Influence respectively. These two factors respectively had acceptable values of Cronbach's Alphas 0.81 and 0.83 .

The 28 items of perceived importance of accommodation information were subjected to exploratory factor analysis. It was appropriate to conduct the factor analysis due to the acceptable KMO value (0.89) and Bartlett's Test of Sphericity $(\mathrm{p}<.001)$. After removing items with factor loadings lower than 0.5, three factors with 15 items were produced. These three factors explained $66.02 \%$ of the total variance and had eigenvalues greater than 1 . These three 
ISSN: 2236-269X

DOI: 10.14807/ijmp.v11i1.1021

factors were labeled Location and Reputation Information, Background Information and Shopping and Traveling Information. The Cronbach's Alphas were 0.91, 0.80 and 0.79 respectively.

An initial confirmatory factor analysis produced a poor fit to the data derived from the scale of perceived importance of accommodation information $\left(\chi^{2}=267.71, \mathrm{df}=87, \mathrm{p}=0.000\right.$, $\mathrm{GFI}=0.809$, NFI $=0.793$, CFI $=0.848$, SRMR $=0.110$ ). Based on the modification indices, four items were further removed due to cross loadings. After removing these items, better fit indices were produced $\left(\chi^{2}=86.86, \mathrm{df}=41, \mathrm{p}=0.000\right.$, GFI $=0.910$, NFI $=0.900, \mathrm{CFI}=0.944$, SRMR $=0.081$ ). The standardized factor loading were from 0.54 to 0.91 . The average variance extracted exceeded the threshold of 0.5 . All composite reliabilities reached the satisfactory level of 0.7 .

Regression tests showed that travel opinion leadership were significantly related to the overall perceived importance of accommodation information $(\beta=0.35, \mathrm{t}=4.52, \mathrm{p}<0.01)$. Regression results showed that travel opinion leadership could significantly contribute to Location and Reputation Information $(\beta=0.41, \mathrm{t}=5.39, \mathrm{p}<0.01)$, Background Information $(\beta=$ $0.18, \mathrm{t}=2.24, \mathrm{p}<0.05)$ and Shopping and Traveling Information $(\beta=0.18, \mathrm{t}=2.15, \mathrm{p}<0.05)$.

The means of opinion leadership among the three groups were 2.90 (LowTOL), 3.51 (MidTOL) and 4.15 (HighTOL) respectively. There was not a significant difference in age among three groups while the HighTOL and MidTOL groups were more likely to be female. The Internet, friends or relatives and accommodation official website were the three most important information sources used by the HighTOL group. There was no statistical difference in using information sources among three groups. That is, the HighTOL group did not use more sources to gain accommodation information than low opinion leadership groups (see Table 1).

Table 1: Descriptive profile of respondents and information resources

\begin{tabular}{lllll}
\hline \multicolumn{1}{c}{ Characteristics } & $\begin{array}{l}\text { LowTOL } \\
(\mathrm{n}=58)\end{array}$ & $\begin{array}{l}\text { MidTOL } \\
(\mathrm{n}=47)\end{array}$ & $\begin{array}{l}\text { HighTOL } \\
(\mathrm{n}=43)\end{array}$ & Chi-Square \\
\hline Age & 21.19 & 21.30 & 21.40 & 1.45 \\
\hline $\begin{array}{l}\text { Gender } \\
\quad \text { Female }\end{array}$ & $24(41.4)$ & $31(66.0)$ & $26(60.5)$ & $7.14^{*}$ \\
$\quad \begin{array}{l}\text { Male } \\
\text { Resources used to search }\end{array}$ & $34(58.6)$ & $16(34.0)$ & $17(39.5)$ & \\
accommodation & & & \\
\hline$\quad$ Internet & & & \\
$\quad$ Guide books & $53(91.4)$ & $45(95.7)$ & $43(100)$ & 4.11 \\
$\quad \begin{array}{l}\text { Friends or relatives } \\
\text { Travel Center }\end{array}$ & $10(17.2)$ & $11(23.4)$ & $15(34.9)$ & 2.67 \\
$\quad$ Accommodation official website & $17(29.3)$ & $23(48.9)$ & $17(39.5)$ & 0.37 \\
$\quad$ Travel Agencies & $7(12.1)$ & $7(14.9)$ & $7(16.3)$ & 0.39 \\
& $9(15.5)$ & $7(14.9)$ & $9(20.9)$ & 0.71
\end{tabular}


INDEPENDENT JOURNAL OF MANAGEMENT \& PRODUCTION (IJM\&P)

http://www.ijmp.jor.br

v. 11, n. 1, January-February 2020

ISSN: 2236-269X

DOI: 10.14807/ijmp.v11i1.1021

$\begin{array}{lllll}\text { Magazines } & 3(5.2) & 8(17.0) & 6(14.0) & 3.95 \\ \text { Past experiences } & 12(20.7) & 9(19.1) & 12(27.9) & 1.14 \\ \text { Accommodation brochures } & 5(8.6) & 5(10.6) & 4(9.3) & 0.13\end{array}$

A series of one-way ANOVA were performed to examine mean differences in the number of trips, travel opinion leadership and perceived importance of accommodation information among three groups. The results demonstrated that the number of trip taken last year were 4.36 (LowTOL), 5.43 (MidTOL) and 5.93 (HighTOL) respectively ( $\mathrm{F}=4.61$, $\mathrm{p}<0.05)$. There was a significant difference in the number of trip between the LowTOL and HighTOL groups. In other words, the LowTOL group took fewer trips than the HighTOL group did.

Within the content of perceived importance of accommodation information, significant differences were seen in all items of Location and Reputation Information, one item of Background Information (AI8) and all items of Shopping and Traveling Information. The three most important destination information perceived by travel opinion leaders included "sanitation" (AI5, means= 4.77), "service quality” (AI3, means= 4.65) and "other customers' comments" (AI2, means=4.51) and “comfort” (AI4, means = 4.51). HighTOL or MidTOL perceived importance of accommodation information was higher than that perceived by LowTOL. That is, different levels of travel opinion leadership would influence the perception of important information in accommodation (see Table 2).

Table 2: Comparison of travel frequency and perceived importance of accommodation information

\begin{tabular}{|c|c|c|c|c|c|}
\hline & \multicolumn{3}{|c|}{ Travel Opinion Leadership } & \multirow[t]{2}{*}{ F-value } & \multirow[t]{2}{*}{ Scheffe Test } \\
\hline & $\begin{array}{c}\text { LowTOL } \\
(n=58)\end{array}$ & $\begin{array}{l}\text { MidTOL } \\
(\mathrm{n}=47)\end{array}$ & $\begin{array}{c}\text { HighTOL } \\
(\mathrm{n}=43)\end{array}$ & & \\
\hline Number of trip taken last year & 4.36 & 5.43 & 5.93 & $4.61 *$ & $\mathrm{H}>\mathrm{L}^{*}$ \\
\hline \multicolumn{6}{|l|}{ Travel Opinion Leadership } \\
\hline \multicolumn{6}{|l|}{ Advice } \\
\hline $\begin{array}{l}\text { (TOL1) My opinion on travelling } \\
\text { seems not to count with other people.* } \\
\text { (TOL2) When they choose travelling }\end{array}$ & 3.05 & 3.87 & 4.30 & $54.27 * *$ & $\mathrm{H}>\mathrm{L}^{* *}, \mathrm{M}>\mathrm{L} * *, \mathrm{H}>\mathrm{L} * *$ \\
\hline $\begin{array}{l}\text { products, other people do not turn to me } \\
\text { for advice.* }\end{array}$ & 3.09 & 3.83 & 4.33 & $52.30 * *$ & $\mathrm{H}>\mathrm{L}^{* *}, \mathrm{M}>\mathrm{L} * *, \mathrm{H}>\mathrm{L}^{* *}$ \\
\hline $\begin{array}{l}\text { (TOL3) Other people come to me for } \\
\text { advice about choosing travelling } \\
\text { products. }\end{array}$ & 3.07 & 3.85 & 4.28 & $55.38 * *$ & $\mathrm{H}>\mathrm{L}^{* *}, \mathrm{M}>\mathrm{L} * *, \mathrm{H}>\mathrm{L}^{* *}$ \\
\hline \multicolumn{6}{|l|}{ Influence } \\
\hline $\begin{array}{l}\text { (TOL4) I often persuade other people } \\
\text { to buy the travelling products that I like. }\end{array}$ & 2.57 & 2.94 & 3.93 & $46.36 * *$ & $\mathrm{H}>\mathrm{L}^{* *}, \mathrm{M}>\mathrm{L}^{*}, \mathrm{H}>\mathrm{L}^{* *}$ \\
\hline $\begin{array}{l}\text { (TOL5) I often influence people's } \\
\text { opinions about travelling. }\end{array}$ & 2.71 & 3.06 & 3.93 & $41.78 * *$ & $\mathrm{H}>\mathrm{L}^{* *}, \mathrm{M}>\mathrm{L}^{*}, \mathrm{H}>\mathrm{L}^{* *}$ \\
\hline \multicolumn{6}{|l|}{$\begin{array}{l}\text { Perceived Importance of Accommodation } \\
\text { Information }\end{array}$} \\
\hline $\begin{array}{l}\text { Location and Reputation Information } \\
\text { (AI1) Accommodation location }\end{array}$ & 3.97 & 4.30 & 4.49 & $7.34 * *$ & $\mathrm{H}>\mathrm{L}^{* *}$ \\
\hline
\end{tabular}


ISSN: 2236-269X

DOI: 10.14807/ijmp.v11i1.1021

(AI2) Other customers' comments

(AI3) Service quality

(AI4) Comfort

(AI5) Sanitation

Background Information

(AI6) Size of room

(AI7) Accommodation rating

(AI8) Accommodation features

Shopping and Traveling Information

(AI9) Nearby shopping mall

information

(AI10) Traveling times

(AI11) Traveling distance
3.79

4.02

3.98

4.09

3.28

3.31

3.38

3.57

3.64

3.66

4.30
4.38
4.38
4.60

4.51

4.65

4.51

4.77
$\mathrm{H}>\mathrm{L} * *, \mathrm{M}>\mathrm{L} * *$

$\mathrm{H}>\mathrm{L} * *, \mathrm{M}>\mathrm{L} *$

$\begin{array}{ll}7.08^{* *} & \mathrm{H}>\mathrm{L}^{* *}, \mathrm{M}>\mathrm{L}^{*} \\ 13.96 * * & \mathrm{H}>\mathrm{L}^{* *}, \mathrm{M}>\mathrm{L}^{* *}\end{array}$

$\begin{array}{ll}\text { 13.01** } & \mathrm{H}>\mathrm{L}^{* *}, \mathrm{M}>\mathrm{L}^{* *} \\ \text { 9.28** } & \mathrm{H}>\mathrm{L}^{* *}, \mathrm{M}>\mathrm{L}^{*} \\ \text { 7.08** } & \mathrm{H}>\mathrm{L}^{* *}, \mathrm{M}>\mathrm{L}^{*} \\ \text { 13.96** } & \mathrm{H}>\mathrm{L}^{* *}, \mathrm{M}>\mathrm{L}^{* *}\end{array}$

$3.51 \quad 1.08$

$3.51 \quad 0.81$

$3.84 \quad 4.67 * \quad \mathrm{H}>\mathrm{L}^{*}$

\section{L=LowTOL, M=MidTOL, $\mathrm{H}=\mathrm{HighTOL} ;{ }^{*} p<0.05^{* *} p<0.01$}

\section{DISCUSSIONS}

The results of the current study offer empirical evidence that the perceived importance of accommodation information scales is a multidimensional construct. Exploratory and confirmatory factor analyses confirm the reliability and validity of this scale. Accommodation managers should consider these important information items because these items may influence the effectiveness of information search and buying decisions made by potential tourists in the segment.

Moreover, the current study provides empirical evidence regarding the relationship between the perceived importance of accommodation information and travel opinion leadership. The high travel opinion leadership group showed relatively more significant mean differences in tourism information than the low travel opinion leadership group.

The high travel opinion leadership group emphasized the information as to accommodation location, other customers' comments, service quality, comfort, sanitation, accommodation features, nearby shopping mall information, traveling times and traveling distance.

There are some managerial and theoretical implications derived from the current study. From the managerial perspective, knowing this information perceived as important by travel opinion leaders is able to help accommodation managers to accordingly develop and execute marketing strategies. It is a need for them to consider providing needed product information.

Accommodation information about sanitation, service quality and other customers' comments and comfort are more likely to be sought by travel opinion leaders. Special attention should be paid to enhance the value of this information. 
DOI: 10.14807/ijmp.v11i1.1021

Theoretically, the result of the current study is exploratory research for future studies on tourist behavior. Much existing tourism research has examined the tourist information search behavior but the current study closes a research gap by developing a scale of perceived importance of accommodation.

Therefore, it is one the first to apply the concept of travel opinion leader to the concept of perceived importance of accommodation information. The literature on both information search behavior and travel opinion leader is enriched. In addition, the profile of travel opinion leaders from the current study makes relevant contributions to the literature on travel opinion leader and the perceived importance of information search studies.

\section{CONCLUSION}

This study explored the critical accommodation information for travel opinion leaders. Results offer practical and theoretical implications for researchers and practitioners. There are some limitations to the current study. First, students are the samples in this study. The generalizability of the results is limited. Future research can use different samples to compare the findings of the current study.

Second, during the development of the scale, some items are removed because of statistical reasons. It is possible that different groups of tourists may perceive accommodation information differently. Future research can examine the scale developed by this study. Third, the current study only investigates accommodation information. Future research can examine other tourism information, such as destination, transportation or attraction information.

\section{REFERENCES}

CARNEIRO, M. J.; CROMPTON, J. L. (2010) The influence of involvement, familiarity, and constraints on the search for information about destinations. Journal of Travel Research, v. 49, n. 4, p. 451-470.

CHIREGI, M.; NAVIMIPOUR, N. J. (2016) A new method for trust and reputation evaluation in the cloud environments using the recommendations of opinion leaders' entities and removing the effect of troll entities. Computers in Human Behavior, v. 60, p. 280-292.

CHOI, S.; LEHTO, X. Y.; MORRISON, A. M.; JAN. S. C. (2011) Structure of travel planning processes and information use patterns. Journal of Travel Research, v. 51, n. 1, p. 26-40.

COOK, R. A.; HSU, H. C.; TAYLOR, L. L. (2018) Tourism: The Business of Hospitality and Travel, London: Pearson.

COULTER, R. A.; FEICK, L.; PRICE, L. L. (2002) Changing faces: Cosmetics opinion leadership among women in the New Hungary. European Journal of Marketing, v. 36, n. 11/12, p. 1287-1308. 
DOI: 10.14807/ijmp.v11i1.1021

DAVIS, D.L.; GUILTINAN, J. P; JONES, W. H. (1979) Service characteristics, consumer search and the classification of retail services. Journal of Retailing, v. 55, n. 3, p.3-23.

DONATON, S. (2003) Marketing's new fascination: figuring out word-of-mouth. Advertising Age, v. 74, n. 46, p. 18.

FLYNN, L. R.; GOLDSMITH, R. E.; EASTMAN, J. K. (1994) The king and summers opinion leadership scale: revision and refinement. Journal of Business Research, v. 31, n. 1, p. 55-64.

FLYNN, L. R.; GOLDSMITH, R. E.; EASTMAN, J. K. (1996) Opinion leaders and opinion seekers: Two new measurement scales. Journal of the Academy of Marketing Science, v. 24, n. 2, p. 137-147.

FODNESS, D.; MURRAY, B. (1997) Tourist information search. Annals of Tourism Research, v. 24, n. 3, p. 503-523.

FODNESS, D.; MURRAY, B. (1998) A typology of tourist information search strategies. Journal of Travel Research, v. 37, n. 2, p. 108-119.

FODNESS, D.; MURRAY, B. (1999) A model of tourist information search behavior. Journal of Travel Research, v. 37, n. 3, p. 220-230.

GOLDSMITH, R. E.; HOFACKER, C. F. (1991) Measuring consumer innovativeness. Journal of the Academy of Marketing Science, v. 19, n. 3, p. 209-221.

GOLDENBERG, J.; HAN, S.; LEHMANN, D. R.; HONG, J. W. (2009) The role of hubs in the adoption process. Journal of Marketing, v. 73, n. 2, p. 1-13.

GURSOY, D.; MCCLEARY, K. W. (2004) An integrative model of tourists' information search behavior. Annals of Tourism Research, v. 31, n. 2, p. 353-373.

HO, C. I.; LIN, M. H.; CHEN, H. M. (2012) Web users' behavioral patterns of tourism information search: from online to offline. Tourism Management, v. 33, n. 6, p. 1468-1482.

HOWELL, A. P.; SHAW, B. R.; ALVAREZ, G. (2015) Bait shop owners as opinion leaders: a test of the theory of planned behavior to predict pro-environmental outreach behaviors and intentions. Environment and Behavior, v. 47, n.10, p. 1107-1126.

HYDE, K. F. (2008) Information processing and touring planning theory. Annals of Tourism Research, v. 35, n. 3, p. 712-731.

IYENGAR, R.; VAN DEN BULTE, C.; VALENTE, T. W. (2011) Opinion leadership and social contagion in new product diffusion. Marketing Science, v. 30, n. 2, p. 195-388.

JAMROZY, U.; BACKMAN, S. J.; BACKMAN, K. F. (1996) Involvement and opinion leadership in tourism. Annals of Tourism Research. v. 23, n. 4, p. 908-924.

KERSTETTER, D.; CHO, M. H. (2004) Prior knowledge, credibility and information search. Annals of Tourism Research, v. 31, n. 4, p. 961-985.

KIM, D. H.; HOWARD, S. C.; ADLER, H. (2015) What drives café customers to spread eWOM?: Examining self-relevant value, quality value, and opinion leadership. International Journal of Contemporary Hospitality Management, v. 27, n. 2, p. 261-282.

KIM, D. Y.; LEHTO, X. Y.; MORRISON, A. M. (2007) Gender differences in online travel information search: implications for marketing communications on the Internet. Tourism Management, v. 28, n. 2, p. 423-433. 
KIM, S. B.; CHOI, K. W.; KIM, D. Y. (2013) The motivations of college students' use of social networking sites in travel information search behavior: The mediating effect of interacting with other users. Journal of Travel and Tourism Marketing, v. 30, n. 3, p. 238-252.

LAYONS, B.; HENDERSON, K. (2005) Opinion leadership in a computer-mediated environment. Journal of Consumer Behavior, v. 4, n. 5, p. 319-329.

LEE, H.; LAW, R.; MURPHY, J. (2011) Helpful reviewers in TripAdvisor, an online travel community. Journal of Travel \& Tourism Marketing, v. 28, n. 7, p. 675-688.

LEWIS, R.; CHAMBERS, R. E. (2000) Marketing leadership in hospitality: Foundations and practices. New York: John Wiley \& Sons.

LEWIS, R. C.; CHAMBERS, R. E. (1989) Marketing leadership in hospitality, foundations and practices. New York: Wiley.

LI, F.; DU, T. C. (2011) Who is talking? An ontology-based opinion leader identification framework for word-of-mouth marketing in online social blogs. Decision Support Systems, v. 51, n. 1, p. 190-197.

MOUTINHO, L. (1987) Consumer behavior in tourism. European Journal of Marketing, v. 21, n. 10, p. 5-44.

MURPHY, L.; MASCARDO, G.; BENCKENDORFF, P. (2007) Exploring word-of-mouth influences on travel decisions: friends and relatives vs. other travelers. International Journal of Consumer Studies, v. 31, n. 5, p. 517-527.

NAIR, H. S.; MANCHANDA, P.; BHATIA, T. (2010) Asymmetric social interactions in physician prescription behavior: the role of opinion leaders. Journal of Marketing Research, v. 47, n. 5, p. 883-895.

OH, I. K. (1997) Hypothesis tests on the characteristics of opinion leaders: an application to travel. Journal of Travel \& Tourism Marketing, v. 6, n. 2, p. 53-68.

PAN, B.; FESENMAIER, D. R. (2006) Online information search: Vacation planning process. Annals of Tourism Research, v. 33, n. 3, p. 809-832.

PAN, B; LITVIN, S. W.; O’DONNELL, T. E. (2007) Understanding accommodation search query formulation: The first step in putting heads in beds. Journal of Vacation Marketing, $\mathrm{v}$. 13, n. 4, p. 371-381.

POLEGATO, R.; WALL, M. (1980) Information seeking by fashion opinion leaders and followers. Home Economics Research Journal, v. 8, n. 5, p. 327-338.

QUINTAL, V. A.; LEE, J. A.; SOUTAR, G. N. (2010) Tourists' information search: the differential impact of risk and uncertainty avoidance. International Journal of Tourism Research, v. 12, n. 4, p. 321-333.

RAMKISSOON, H.; UYSAL, M. (2011) The effects of perceived authenticity, information search behavior, motivation and destination imagery on cultural behavioral intentions of tourists. Current Issues in Tourism, v. 14, n. 6, p. 537-562.

REISINGER, Y.; MAVODNO, F. (2004) Modeling psychographic profiles: A study of the U.S. and Australian student travel market. Journal of Hospitality \& Tourism Research, v. 28, n. 1, p. 44-65.

ROGERS, E. (1996) Diffusion of Innovation, 4th ed. New York: Free Press. 
DOI: 10.14807/ijmp.v11i1.1021

SMERECNIK, K. R.;ANDERSEN, P. A. (2011) The diffusion of environmental sustainability innovations in North American hotels and ski resorts. Journal of Sustainable Tourism, v. 19, n. 2, p. 171-196.

THEUNS, L. (1992) The significance of youth tourism: Economic dimensions. Acta Turistica, v. 4, n. 2, p. 165-186.

TRUSOV, M.; BUCKLIN, R. E.; PAUWELS, K. (2009) Effects of word-of-mouth versus traditional marketing: findings from an internet social networking site. Journal of Marketing, v. 73, n. 5, p. 90-102.

VALENTE, T. W.; PUMPUANG, P. (2007) Indentifying opinion leaders to promote behavior change. Health Education \& Behavior, v. 34, n. 6, p. 881-896.

VAN ECK, P. S.; JAGER, W.; LEEFLANG, P. S. H. (2011) Opinion leaders' role in innovation diffusion: a simulation study. Journal of Production Innovation Management, v. 28, n. 2, p. 187-203.

WEIMANN, G. (1991) The influentials: Back to the concept of opinion leaders? Public Opinion Quarterly, v. 55, n. 2, p. 267-279.

WEIMANN, G. (1994) The influential: people who influence people. New York: State University of New York Press.

WESBROOK, R. A. (1987) Product/consumption-based affective responses and post-purchase processes. Journal of Marketing Research, v. 24, n. 3, p. 258-270.

YIYI, Z.; GANG, K.; YI, P.; YANG, C. (2018) Understanding influence power of opinion leaders in e-commerce networks: an opinion dynamics theory perspective. Information Sciences, v. 426, p. 131-147. 